\title{
INFLUENCE OF BRISK WALKING EXERCISE ON BLOOD PRESSURE AMONG ESSENTIAL HYPERTENSION PATIENTS
}

\author{
Ika Dwi Rachmawati1) Angga Sugiarto 2) Tulus Puji Hastuti 2) \\ ikadwirachmawati@gmail.com \\ Jl. Perintis Kemerdekaan, Magelang, Central Java
}

\begin{abstract}
Background: Complementary Therapies now are become commonplace and preferred by patients. The one which is growing is Brisk walking exercise complementary therapy, which has correlation with blood pressure.

Research purposes: to prove the effect of brisk walking exercise on blood pressure in patients with essential hypertension

Method:This type of research is a quasi exsperiment approach to non equivalent control group design pretest and posttest, where the intervention group of hypertension patients taking anti-hypertensive medication and given treatment in the form of brisk walking exercise 30 minutes for 8 sessions in 2 weeks, while the control group of patients hypertension who just take drugs. Sampling was done by purposive sampling method were 116 patients with essential hypertension were treated in Public health centers Secang 1 . Blood pressure measurements performed at the beginning and end of the study. Statistical test using Wilcoxon test and Mann-Whitney.

Results: results of the study showed a mean decrease in blood pressure, with significance at $p=0.001$ systolic pressure and diastolic pressure of $p=0.001$.

Conclusion: Brisk walking exercise can be done as a complementary therapy in patients with essential hypertension. Brisk walking will exercise resisted vascular so that the end result can lower the blood pressure.

keyword: hypertension; brisk walking exercise; blood pressure

1) Student of Magelang Nursing Department, Poltekkes Kemenkes Semarang

2),3) Lecturer of Magelang Nursing Department, Poltekkes Kemenkes Semarang
\end{abstract}

Background. The incidence of hypertension in almost all countries show a high rate. The world in 2014 there were 600 million people with hypertension. In Indonesia, according Riskesdas (2013) shows the prevalence of hypertension of $25.8 \%$, while according to the provincial health office central Java (2014) there were $57.89 \%$ of hypertensive patients of the total cases of non-communicable diseases. According to health official Magelang regency (2017) there were 17018 cases of patients with essential hypertension and in Secang 1 Public health center there were 1601 cases of patients with essential hypertension.

In according to the recommendation of the World Health Organization-International Society Of Hypertension (WHO-ISH) and the Joint National Committee (JNC VI) in dealing with patients with mild hypertension, especially hypertension, can be done with sports activities. Activities that can be done in the form of physical activity practice is to brisk walking exercise.

Brisk walking exerciseis is the one of aerobic exercise that is a part of moderate exercise in patients with 
hypertension by using brisk walkingtechnique for 20-30 minutes. The result of brisk walking exercise is to reducethe risk of mortality and morbidity in hypertensive patients through the mechanism of burning calories, maintain weight, helps the body relax and increase the compound beta-endorphins which can reduce stress but it also affects cardiac output and the resistance of blood vessels so that the final result can decrease the blood pressure. (Kowalski in Sukarmin \& Nurachmah, 2013). The target of blood pressure reduction that is haven'toptimal and the lack of implementation of brisk walking exercise in the management of hypertensive patients in Secang 1 public heath center, which motivate this study. The purpose of this study was to determine the effect of brisk walkingexercise on blood pressure in hypertensive patients.

Objective. The purpose of this study is to determine the effect of brisk walking exercise on blood pressure patients with essential hypertension.

\section{Results and Discussion}

Table 1. The frequency distribution by Sex and Age $(\mathrm{n}=116)$

\begin{tabular}{ccc}
\hline variables & frequency & $\%$ \\
\hline Gender & & \\
Man & 54 & 46.6 \\
woman & 62 & 53.4 \\
Age & & \\
$36-45$ & 9 & 7.8 \\
$46-55$ & 54 & 46.6 \\
$56-65$ & 53 & 45.7 \\
\hline
\end{tabular}

Methods. The method which used is quasi-experimental with non equivalent control group pretestposttest design,the measurement of blood pressure is using digital spignomanometer and the measurement at the beginning and end of the study both intervention and control group. The inclusion of criteria include the samples hypertension diagnosed with blood pressure 140/90 mmHg - 159/99 $\mathrm{mmHg}$, taking medication and treatment at Secang 1 public health center, aged 40-60 years, had never done brisk walking exercise, haven't upper and lower extremity weakness, haven't musculoskeletal system weaknesses, haven't a visual impairment problems, and able to move independently. The excluding criteria are: not willing to become respondents, had experiencing headache, suffered a stroke, heart disease, kidney failure and AMI (acute miokardinfark), have a chronicdiseas. Data analysis included univariate and bivariate using Wilcoxon statistical test and MannWhitney.

Table 2. Distribution of Blood Pressure Pre-Test and Post-Test Intervention Group and a control group $(\mathrm{n}=116)$

\begin{tabular}{ccccc}
\hline Group & $\begin{array}{c}\text { Blood } \\
\text { pressure }\end{array}$ & Mean & SD & Max-Min \\
\hline $\begin{array}{c}\text { Inter- } \\
\text { vention } \\
\text { Pre-test }\end{array}$ & systole & 150 & 7.762 & $160-140$ \\
& diastole & 88.8 & 5426 & $99-77$ \\
Post-test & systole & 140 & 8.593 & $157-125$ \\
& diastole & 83.5 & 3.766 & $92-74$ \\
diff & systole & 9.9 & 6.791 & $32-(-1)$ \\
& diastole & 5.3 & 4.580 & $19-(-4)$ \\
\hline Control & & & & \\
Pre-test & systole & 151.4 & 7.269 & $161-140$ \\
& diastole & 89.4 & 5.144 & $98-78$ \\
post- & systole & 149.7 & 6.942 & $164-138$ \\
test & & & & \\
& diastole & 87.7 & 4,413 & $96-78$ \\
diff & systole & 1.6 & 3.697 & $-6-11$ \\
& diastole & 1.7 & 4.953 & $14-14$ \\
\hline
\end{tabular}


Table 3 Changes in systolic and diastolic blood pressure Before And After

Do Brisk Walking Exercise

\begin{tabular}{lcc}
\hline \multicolumn{1}{c}{ Group } & $\begin{array}{c}\text { Median } \\
\text { (minimum- } \\
\text { maximum) }\end{array}$ & P value \\
\hline Intervention & & \\
TD systole & $150(140-$ & 0,000 \\
pre-test & $160)$ & \\
TD systole & $140(125-$ & \\
post-test & $157)$ & \\
Diastole TD & $89(77-99)$ & 0,000 \\
pre-test & $83(74-92)$ & \\
TD diastole & & \\
post-test & & \\
Control & & \\
TD systole & $153(140-$ & 0,001 \\
pre-test & $161)$ & \\
TD systole & $150(138-$ & \\
post-test & $164)$ & \\
Diastole TD & $90(78-98)$ & 0,005 \\
pre-test & $89(78-96)$ & \\
TD diastole & & \\
post-test & & \\
\hline
\end{tabular}

table 4 Differences Decreased systolic and diastolic blood pressure group Intervention and Control Group

\begin{tabular}{lcc}
\hline & $\begin{array}{c}\text { median } \\
\text { (Minimum- } \\
\text { Maximum) }\end{array}$ & p value \\
\hline $\begin{array}{l}\text { diff systole } \\
\text { intervention }\end{array}$ & $9(-1-32)$ & 0,000 \\
diff systole & $2(-6-14)$ & \\
control & & \\
$\begin{array}{l}\text { Diff diastole } \\
\text { intervention } \\
\begin{array}{l}\text { Diff control } \\
\text { diastole }\end{array}\end{array}$ & $5(-4-19)$ & 0,000 \\
\end{tabular}

Based on the research that has been done of respondents who dominate in this study were female respondents. The results of data showed that female respondents tend to get hypertension than in men, which are $53.4 \%$ of the respondents were female and $46.6 \%$ were male. These results are in line with the Singalingging'sopinions (2011), which, say that the average of women will increased the risk of high blood pressure (hypertension) after menopause is aged over 45 years.

Premenopausal women are protected by the hormone estrogen which have a role in increaseHigh Density Lipoprotein (HDL)levels. The low HDL cholesterol and high lowdensity lipoprotein (LDL) are affect the process of atherosclerosis (Anggriani, 2009).

Kurniasih (2011), says that the incidence of hypertension increases with age, it is due to the decreaseof elasticity of blood vessels. Based on the research, people aged 46 years to 55 years is quite dominating, as many as 54 respondents.

Hypertension is one of the degenerative disease, with increase of age, the blood pressure will also increase due to some physiological changes. Additionally in the elderly peoplecommonly increase the blood pressure that associated with decreasing of blood vessel elasticity and structural changes such as constriction of the lumen of blood vessels thus increasing blood pressure (Potter \& Perry, 2010).

Blood pressure in the elderly is likely to be high so that the elderly have the high riskof hypertension. Increasing age resulted in increase of blood pressure due to the arterial wall in the elderly will have thickening because of collagen accumulation in the muscle layer, so that the blood vessels will be narrowed and become rigid (Anggraini in Novitaningtyas, 2014). Based on research Heryudarini (2008) there was a significant relation between age and systolicand diastolic blood pressure. Increase in the age of 1 year will increase systolic blood pressure as much as $0.493 \mathrm{~mm} \mathrm{Hg}$ and diastolic blood pressure as much as $0.189 \mathrm{mmHg}$. 
Treatment which is given to respondents intervention group in the form of exercise is brisk walking exercise as long as 30 minutes for 8 sessions in two weeks, made four days in a row, then rest two days and resumed the training again for 4 days in a row, in addition the respondents of intervention group also consume antihypertensive drugs. While the control group respondents only consume antihypertensive drugs.

The results of differences of pre-test and post-test systole intervention group obtained $\mathrm{p}=0.001$ $(\mathrm{p}<0.05)$ and diastole obtained $\mathrm{p}=$ 0.001 ( $p<0.05)$, which means there is a significant difference between pre-test and post- test systole and diastole in the intervention group after get brisk walking exercise, in addition to do brisk walking exercise to the respondents in this group were still consume anti-hypertensive drugs.

The study also put to the test of pre-test post-test in the control group which the respondents only consume anti-hypertensive drugs, the different test results ofsystolic pre-test and posttest obtained $p=0.001(p<0.05)$ and at distol obtained $\mathrm{p}=0.005(\mathrm{p}<0.05)$, which means there is a significant difference between pre-test and posttest systole and diastole in the control group. The results in this group have a significant difference due to the control group respondents still consume the medicine.

There are several factors that can affect blood pressure are cardiac output and peripheral vascular resistance. Where cardiac output is the amount of blood pumped by the ventricle into the pulmonary circulation and circulation system within one minute, cardiac output was affected by the stroke volume and heart rate. Peripheral resistance is influenced by the flexibility of arteries, arterial diameter and blood viscosity (Ronny, 2010)

The difference test between the intervention and control groups were also performed on diff systole and diff diastole in the intervention group and the control group. The results of the test diff systole is $p=0.001(p<0.05)$ and diastolic diff test is $\mathrm{p}=0.001$ ( $\mathrm{p}$ $<0.05)$. This result means that there is a significant difference in the reduction betweenintervention and control groups. The intervention group received a complementary therapy which the combination between pharmacological and nonpharmacological therapy, in this case that the anti-hypertensive drugs and do brisk walking exercise. These results indicate a mean blood pressure reduction, in which the final outcome in the intervention group there is a decrease in systolic blood pressure of $9.9 \mathrm{mmHg}$ (SD 6.8) and a decrease in diastolic pressure of $5.3 \mathrm{mmHg}$ (SD 4.6), whereas in the control group systolic pressurereduction is $1.6 \mathrm{mmHg}$ (SD 3.7)

That results were consistent with studies conducted by Utami, Utomo \& Rolita (2013) which told that the brisk walkingexercise will quicken coronary blood flow into the heart. Thus, the adequacy of the heart muscle of oxygen the heart muscle are met and maintained to still be beating. Flexibility of the arteries that trained tocontraction and relactation will be helped by convulsion of muscles located around the walls of blood vessels while doing brisk walking, so that arterial resistance will also be reduced which in turn can accelerate blood flow. The end result, blood pressure tends to be lower and cell adhesions that can cause blood clots block blood vessels will also be 
reduced. Research by SukarminNurachmah \& Gayatri, (2013) also have shown that brisk walking exercise can lower blood pressure which is the average drop in systolic pressure and diastolic $\mathrm{mmHg}$ 5,048 4,429 $\mathrm{mmHg}$.

Dilation of blood vessels also will caused decrease the distance between the blood and the active cell, as well as the distance of diffusion of $\mathrm{O} 2$ and metabolic substances greatly reduced to improve cell function because of sufficient blood cells, oxygen and nutrients in the cell (Ganong 2008). Brisk walking exercise work through the reduction of peripheral resistance, when the muscles are contracted through physical activity, so it will increase blood flow 30 times when performed rhythmic contractions, dilatation spinchter percapiler and arterioles causes increased the capillary'sexposure 10-100 times.

Physical exercise activity will give a good effect against a wide range of systems that work in the body, one of them is the cardiovascular system, in which the physical exercise properly and regularly will make the heart work efficiency. Efficiency of the heart or the heart's capacity will be increased in accordance with the changes. It may become the changes in heart rate, stroke volume, and cardiac output (Daenuri in Syatria, 2006). This statement is equal with the study by Harnia (2014) showed significant figure of 0,003 . Because the value of ( $p$ $<0.05$ ), it can be concluded that blood pressure pre and post intervention of regular physical exercise significantly so that there is the effect of regular physical exercise on blood pressure.

Conclusion and Suggestions. Brisk walking exercisecan be used as a complementary therapy in lowering blood pressure in patients with essential hypertension. Its application can be done independently or with assistance

\section{References}

Anggraini, AD., Waren, S., Situmorang, E., Asputra,h., Silahaan, SS. (2009). FaktorFaktor Yang Berhubungan Dengan Kejadian Hipertensi Pada Pasien Yang Berobat Di Poliklinik Dewasa Puskesmas Bangkinang Periode Januari Sampai Juni 2008 . Fakultas Kesehatan. Universitas Riau. File of DrsMed-FK UNRI : $1-41$.

(ejournal.stikesyarsi.ac.id/index.php/J AV1N1/article/download/18/146, diakses 1 April 2018).

Brunner \& Sudart (2013). Keperawatan Medikal Bedah. EGC: Jakarta.

Dinas Kesehatan Provinsi Jawa Tengah (2014). Profil Kesehatan tahun 2014.

(www.depkes.go.id/resources/dow nload/...PROVINSI_2014/13_Jate ng_2014.pdf, diakses 8 januari 2018)

Ganong, W. F. (2008). Buku Ajar Fisiologi Kedokteran Edisi 22. Jakarta : EGC.

Heryudarini $\mathrm{H}$, Hardinsyah, Budi S, Imam, E. (2008). Hubungan indeks massa tubuh, jenis kelamin, usia, golongan darah dan riwayat keturunan dengan tekanan darah pada pegawai negeri di pekan baru. Jurnal Penelitian Gizi dan Makanan.31(2). Diaskses tanggal 1 April 2018.

Kamal, M., Kusmana, D., Hardinsyah., Setawan, B., \& Damanik, R. (2013). Pengaruh olahraga jalan cepat dan diet terhadap tekanan darah penderita prahipertensi pria. Jurnal Kesehatan Masyarakat Nasional, $\quad 7$ (6), 279-283. 
(http://jurnalkesmas.ui.ac.id/kesma s/article/view/38, diakses 10 januari 2018).

Kurniasih, I. Analisis Faktor Terjadinya Peningkatan Tekanan Darah Pada Penderita Hipertensi. Jurnal Eduhealth. 2013; 3. (http://docplayer.info/amp/697234 52-Issn-volume-3-nomor2september-evaluasi-pascarevitalisasi-pelayanan-kesehatandi-posyandu-kota-surabaya-tahun2013.html, diakses tanggal 1 april 2018)

Novaningtyas, T. Hubungan Karakteristik (Umur, Jenis Kelamin, Tingkat Pendidikan) Dan Aktivitas Fisik Dengan Tekanan Darah Pada Lansia di Kelurahan Makamhaji Kecamatan Kartasura Kabupaten Sukoharjo. 2014 (eprints.ums.ac.id/29084/9/02._Naska h_Publikasi.pdf, diaksestanggal 1 April 2018).

Pusat Data Dan Informasi Kementrian Kesehatan Indonesia (Infodatin). (2016). Hipertensi. (www.depkes.go.id, diakses 14 Januari 2018)

Potter, P \& Perry A (2010). Fundamental of nursing. Singapore: Elsevier.

Riset Kesehatan Dasar (Riskesdas). (2013). Badan Penelitian dan Pengembangan Kesehatan Kementrian RI tahun 2013. (www.depkes.go.id/resources/dow nload/general/Hasil\%20Riskesdas $\% 202013$, diakses 8 Januari 2018).

Ronny,S. F. (2008). Fisiologi Kardiovaskuler : Berbasis Masalah Keperawatan. Jakarta: EGC.
Subakti, S. (2014). Pengaruh latihan jalan kaki 30 menit terhadap penurunan tekanan darah pada pasien hipertensi di Rumah Sakit Umum

JurnalPengabdianKepada

Masyarakat, 28 (77), 1-15. (

https://jurnal.unimed.ac.id/2012/in dex.php/jpkm/article/view/6868 , diakses 10 Januari 2018)

Singalinggi, G. (2011). Karakteristik Penderita Hipertensi di Rumah Sakit Umum Herna Medan 2011. Medan 1-6. (repository.usu.ac.id/bitstream/12345 6789/43330/2/Reference.pdf, diakses 1 April 2018).

Sukarmin., Nurachmah, E., \& Gayatri, D. (2013). Penurunan tekanan darah pada pasien hipertensi melalui brisk walking exercise. Jurnal Keperawatan Indonesia, 16

(1), 33-39. (https://www.neliti.com/id/publicat ions/108910/penurunkan-tekanandarah-pada-pasien-hipertensimelalui-brisk-walking-exercise, diakses 10 Januari 2018).

Triyanto, E (2014). Pelayanan keperawatan bagi penderita hipertensi secara terpadu. Yogyakarta : Graha ilmu.

Utami, G., Utomo, W., \& Riolita, M. (2016). Analisis tekanan darah lansia yang melakukan kegiatan olahraga jalan pagi. Jurnal Ners Indonesia, 6 (1), 76-84. (https://ejournal.unri.ac.id/index.php/J NI/article/download/4361/4179, diakses 10 Januari 2018). 